\title{
Exploring Uncounted Contribution of Women in Bangladesh: Barriers, Implications and Opportunities
}

\author{
Tania Haque \\ Department of Women and Gender Studies, University of Dhaka, Bangladesh
}

Copyright $\bigcirc 2016$ by authors, all rights reserved. Authors agree that this article remains permanently open access under the terms of the Creative Commons Attribution License 4.0 International License

\begin{abstract}
Work is typically divided along gender lines with men being responsible for the outside work and as the main income- earner and women for housework and child care. Women's unpaid work is not recognized and therefore, women are considered as passive dependents. Non-recognition of women's activity not only leads to undervaluation of economic contribution but also contributes to their lower status in society relative to men in Bangladesh. Therefore unpaid work is not a gender-neutral bundle of chores that women perform out of comparative advantage or lower resources but instead it is an integral part to the reproduction of unequal power relations between men and women.
\end{abstract}

Keywords Unpaid Work, Empowerment, Recognition of Unpaid Work

\section{Section One}

\subsection{Introduction}

The resilience of informal economic activities demonstrates all the uneven development of the world economy and also the uneven ways of utilizing labor throughout the world. A focus on formal economy and employment statistics ignore the heterogeneity in the forms of work and do undermine the continued economic importance of kinship and community ties. In popular usage the terms "work" or 'labor' have come to imply the exchange of one's time and effort for wages. Economics have relied outwardly on the endless supply of care work provided by women to sustain families, societies, and labor force without giving it social and economic value. This androcentric conception considers only the paid as visible and it fails to address the value of women's society activities, which fall outside the market, and considered as non-market work. There is a misperception that those who are economically productive do "real work"; unpaid care work is not real work (Shelton, 1996). Time is one of the society's most important economic resources. But time spent on unpaid care work has gone largely unnoticed and ignored. Shelton reflects that this is primarily because "what goes on in the household is not intrinsically attention-grabbing since (1) women do it, (2) it is not in the public sphere, and (3) it is not subject to change through policy" $(1992 ; 64)$. So the question arises, why does unpaid care work remain women's work?

At the macro and micro levels of gender analysis, the gendered division of work and responsibilities imply labor immobility and less income on the part of women. Men on the other hand dominate the market economy and consequently have more income. This further translates into unequal power relations in the household as a consequence of gender imbalance in terms of income (World Bank, 2001). The widespread entry of women into labor work since 1980's has challenged the presumption that women's primary role is that she is the caretaker for home and family only (Shelton, 1996). In Bangladesh, a husband's ability to provide economically for the family is intimately linked with the notions of masculinity as well as personal and family honor. But this social content is changing. Education and employment have provided women with new avenues to assert themselves. More importantly this particular paid work suggests new ways for women to identify their values, reclaim their identities and define success of their own terms (McKenna, 2002).It has expanded the number of women who are able to achieve self-reliance, economic agency within the family which had made their significant economic contribution to their families. At the same time, it also challenges the myth of the male breadwinner model of the family in Bangladesh (Mahmud, 2002). 1 Although women are the major producer of non-market economy but current system of GDP measurement excluded them from mainstream and made them invisible in national statistics. Currently, women's growing earning power and

1 Naila Kabeer and Simeen Mahmud, Globalisation, Gender and Poverty: Bangladeshi Women Workers in Export and Local Markets), Journal of International Development, Volume 16, issue 1, 2004 
commitment to the paid workforce have made some families more financially dependent on women. Therefore the system of care provision is under strain in some contexts and for some social groups.

The paper argues that inclusion of unpaid work will reflect women's actual contribution to the national income. The major objective of this paper is to develop a new system of counting unpaid work through decomposing the conventional GDP by gender in Bangladesh. The current paper is analyzed by socialist -feminist perspective to address some limitations in the conventional theories. Since socialist feminist thought is based on the premise that the public and private spheres are interwoven and interdependent through the idea of reproduction and production. The paper consists of five sections: The next section of the paper sketches the background of the study. It highlights that unpaid work is creating the secondary status for women and demonstrates how contextual factors sustain their subordinate position in Bangladesh. This section also documents some major changes of women's involvement in the labor market that have taken place in recent decades. Although these changes are related to the expansion of women's opportunities and choices, there is a new crisis for women to bear the 'double burden'. The section three stated the definition of work, unpaid work and perception towards work. Section four critically explains the side effect towards women due to this unrecognized work such as; economic costs and social costs. Section five pointed out the need for measurement and value creation of unpaid work through which invisible work will become visible and non-worker women will be recognized as worker.

\subsection{Sequencing the Methodology and Data Collection}

The approach used in this study is based on a feminist standpoint, engaging a level of consciousness about one' social location and that location may justify their social position (Harding, 1992). Using women's lives as a starting point decreases the partiality and distortions in our images and perceptions of social relations (Harding 1992:181). Articulating experience according to Harding $(1992 ; 178)$ is a crucial means of creating knowledge for all and all women's lives are valuable for generating feminist knowledge. This process of articulating knowledge is central to consciousness- raising and for women's voices to be heard. Thus there is a need for them to speak from their standpoint, perspective and experience. The analysis is based on the secondary data in nature and relies on multiple resources. Academic contributions in books, journals, government documents as well as published and unpublished works were explored. In addition numerous updated websites on this particular issue covering contributions and innovations worldwide are also included. The literature facilitated both the theoretical understanding of the care economy concept as well as challenges.

Research grounder in this type of inquiry provides a set of sensitive and complex analytical tools for understanding the structures, processes and outcomes of unpaid work towards women. The construction of reproduction and production with its emphasis on unpaid and paid work highlights the artificial boundaries amongst market, the family and the state. However, this paper is simply a way of enabling to share women's experiences and make their voices heard. Therefore, the aim of our review is to offer readers a comprehensive outlook on complex and ample new data on unpaid work. It represents a timely effort to synthesize the available literature and to shed light of different levels of analysis adopted by researchers. The data has been analyzed by using gender lens.

\section{Section Two}

\subsection{Background of the Study}

The economic crisis especially of the lost decade of the1980's has increased the importance of women's contribution to the household; it also has placed heavy burden on women to meet the rising cost of living, cuts in government services and high levels of unemployment (Safa 1995:82-3). Policies based on market models ignore women's domestic and reproductive roles (Pearson, 1992). Moser (1993) opines that women, because of their multiple responsibilities assume disproportionate share of the burden of adjusting adverse economic circumstances. Socio-cultural expectations and norms constrain the development of women's capabilities, resulting in women's concentration in unpaid household work (Kabeer, 1995). In patriarchal society women's mobility is synchronized in order to control their sexuality, production and reproduction. Women's devalued status within the family and society in Bangladesh is reinforced by Purdah remain and confine them to their reproductive responsibilities and those forms of productive work that can be carried out within the home (Kabeer, 2008). These unequal social and cultural circumstances depict women with unequal human capabilities and women are simply not treated as equal with men in the sphere of individual rights. The religious misinterpretation also creates some major obstacle for women to go out as worker. They encourage women to stay at home as ideal homemakers. In a context in which women have learnt from childhood to internalize the inferior status ascribed to them by their society (Kabeer, 2008). Women are generally regarded as subordinate to their male counterparts, have less voice, less autonomy, fewer opportunities and lowered self-esteem. This to a certain extent has to do with the informal cultural norms, inequitable practices and ideologies that affect the women's ability to secure their entitlements and access to opportunities. The United Nations System of National Accounts (SNA) as applied to Bangladesh and the country's labor force statistics both take into account only market work and provide estimates of national income which describe the outcome of the economy but fail to capture the total production of the country since it excludes the portion of non 
market production which is mainly produced by women (Hamid, 1996). Since women are the major contributors of the economy through their involvement in non market labor, such theoretical application have effectively barred them from being reflected in national statistics and have hidden their actual efforts (Hamid, 1996).

Demographic changes that have emerged in fertility have limited the capacity of families to perform care-giving responsibilities. In Bangladesh fertility rate has declined, which may also an indication not only lowering fertility rates but also increasing neucleariazation of families from more traditional norm joint families. On the other hand average life expectancy has increased from 50.33 years in 1965 to 70.06 in 2013 (Index mundi). Another remarkable point is women's (71.98) life expectancy slightly higher than men (68.21). This means there are fewer people in the household who can provide care to elderly population. Lopita Haq (2015) addressed that increase women participation in the labor force reduces care of aging populations, greater investments in girls education is squeezing the time that used to be spent by women in unpaid work. In addition women's increasing presence in national and international labor migration and migration for work also raises questions about the traditional family structure and gender roles. When women migrate, it is not that the traditional gender roles are rearranged in a patriarchal social setting; rather the burden of household work is most likely transferred to another female family member (Haq, 2015). Another notable phenomenon is female international migration. Welfare and overseas employment has recently taken up the initiative to facilitate the domestic workers with measures to ensure their safety. This indicates that Bangladesh government is now giving some thoughtful attention of paid care work in the context of migration. In addition BBS recently published on Pilot Time use survey 2012 where they have shown the result of time distribution both for men and women. But the intention of this survey was only done to improve the statistical data and did not connect the cost of uncounted work performed by women and to connect the survey findings with the mainstream accounting. But, there is hardly a few research appears to have been conducted to date to estimate the value of women's unpaid work, in the context of Bangladesh. Moreover, women's contribution is under-represented in Bangladesh since labor force surveys have been unable to capture their multiple activities effectively. Thus this study will mark out the economic significance of unpaid work and or its inclusion within macroeconomic framework of national income accounting.

\subsection{Labor Market Participation of Women in Bangladesh}

According to World Bank report female labor force in Bangladesh was 41.10 in 2009, published in 2010. Labor force comprises people ages 15 and older that meet the International Labor Organization's definition of the economically active population. In Bangladesh 3.25 percent of employed women are working in the government sector and 8.25 percent in the private sector. The remaining 89.5 percent are employed in the informal sector. Women worked longer hour than men, contributing $54 \%$ to $60 \%$ of total work time, in subsistence economy women contributed $60 \%$ to $80 \%$, in domestic sphere $84 \%$ to $95 \%$.

\begin{tabular}{|c|c|c|c|}
\multicolumn{2}{c}{ Labor force Characteristics } & \multicolumn{2}{c|}{ Labor Force survey } \\
\hline & $2002-03$ & $2005-06$ & 2010 \\
\hline Total & 46.3 & 49.5 & 56.7 \\
\hline Male & 36.0 & 37.3 & 39.5 \\
\hline Female & 10.3 & 12.1 & 17.2 \\
\hline Urban & & & \\
\hline Total & 11.3 & 11.7 & 13.3 \\
\hline Male & 8.6 & 8.9 & 9.3 \\
\hline Female & 2.7 & 2.8 & 4.9 \\
\hline Rural & & & \\
\hline Total & 35.0 & 37.8 & 43.4 \\
\hline Male & 27.4 & 28.5 & 30.2 \\
\hline Female & 7.6 & 9.3 & 13.3 \\
\hline
\end{tabular}

Table: labor force survey, 2010.

\subsubsection{How Much Unpaid Work is Done and by Whom?}

The total work time contributed by women both in developing and developed countries two third is spent in unpaid work and one third in paid work. Men in developed countries, the shares are reversed and in developing countries roughly one forth (ILO, 2007). The unequal distribution of unpaid work between women and men are substantially linked to sex segregated labor market and sexual discrimination (Gibson, 2006). The most striking feature of unpaid work is women and men perform it disproportionately in developing and developed countries alike. Non-market production both subsistence work and housework is a major sector of economy in Bangladesh (Hamid, 1996). Women's contribution is underrepresented in Bangladesh since labor force surveys have been unable to capture their multiple activities adequately. Hamid (1996) has shown that women spend more time in unpaid work than men. Bangladesh time allocation studies articulated that women's total work load ranged from $50 \%$ to $58 \%$ and women's hours to total work remained more or less for all socio economic groups (Khuda, 2008). Further findings included that:

a Conventional GDP estimates capture 98\%of men's production but only $47 \%$ of women's production.

b Under the presence of United Nations System of National Accounts (UNSNA) production boundary definitions $95 \%$ of nonmarket production is excluded.

c In rural areas women contribute $53 \%$ and men $47 \%$ of total time.

d Of the total time spent on the non -market work, women contribute $89 \%$ and men $11 \%$.

e Men have 12 percent more leisure time than women 
Table 1. Percentage distribution of population aged 15 years and above by economic category, residence and sex, 2005-06

\begin{tabular}{|c|c|c|c|c|c|c|c|c|c|}
\hline \multirow{2}{*}{ Economic category } & \multicolumn{3}{|c|}{ Bangladesh } & \multicolumn{3}{c|}{ Urban } & \multicolumn{3}{c|}{ Rural } \\
\cline { 2 - 13 } & Both sex & Male & Female & Both sex & Male & Female & Both sex & Male & Female \\
\hline Population aged 15+(million) & 84.6 & 43.0 & 41.6 & 2.1 & 10.7 & 10.4 & 63.5 & 32.5 & 31.2 \\
\hline Total & 100.0 & 100.00 & 100.00 & 100.00 & 100.00 & 100.00 & 100.00 & 100.00 & 100.00 \\
\hline Labor force & 58.5 & $\mathbf{8 6 . 8}$ & $\mathbf{2 9 . 2}$ & 55.7 & 83.1 & 27.4 & 59.4 & 88.0 & 29.8 \\
\hline Not in Labor force & $\mathbf{4 1 . 5}$ & 13.2 & $\mathbf{7 0 . 8}$ & 44.3 & 16.9 & 72.6 & 40.6 & 12.0 & 70.2 \\
\hline Total labor force & 100.0 & 100.00 & 100.00 & 100.00 & 100.00 & 100.00 & 100.00 & 100.00 & 100.00 \\
\hline Employed & 95.8 & 96.7 & 93.0 & 95.7 & 96.5 & 93.3 & 95.8 & 95.7 & 92.9 \\
\hline Unemployed & 4.2 & 3.4 & 7.0 & 4.3 & 3.6 & 6.7 & 4.2 & 3.3 & 7.2 \\
\hline Not in labor force & 100.0 & 100.0 & 100.0 & 100.0 & 100.0 & 100.0 & 100.0 & 100.0 & - \\
\hline Household work & 68.7 & 6.2 & $\mathbf{8 0 . 8}$ & 62.7 & 7.8 & $\mathbf{7 5 . 8}$ & 70.0 & 5.5 & $\mathbf{8 2 . 5}$ \\
\hline Student & 18.7 & 65.4 & 9.6 & 23.4 & 63.7 & 13.8 & 17.0 & 66.1 & 8.2 \\
\hline Others & 12.6 & 28.4 & 9.6 & 13.9 & 28.5 & 10.4 & 12.0 & 28.4 & 9.3 \\
\hline
\end{tabular}

Source: http://www.bbs.gov.bd/dataindex/labour_\%20force05-06.pdf

Women in Bangladesh work on average 16 hours a day are involved in various unpaid housework. Therefore women work about 771.2 million hours a year at household work with an estimated value of somewhere between US\$ 69.81 and 91.03 billion, if these work were added to GDP than GDP would more than double (Biswas and Ruma, 2007). Islam (2013) an estimate of the Bangladesh Home workers women association (BHWA) discovered that that annual contributions of home based workers to the GDP is about Tk 150 billion(US $\$ 2.59$ billion). This paper also shows that women contribute 41 per cent to total GDP2. Hamid (1996) found that the average women in Bangladesh contribute 4,765 taka (US\$ 133.14) annually economy through her unpaid work of which $3 \%$ is from subsistence production and $95 \%$ from household work. For men the figure is 219 taka (US\$ 6.19) 29\% from own account subsistence production and $71 \%$ from housework. Hamid calculated that annually over 188 billion taka (US\$ 5.25 billion) worth of work uncounted in national statistics. Hamid further calculated that Bangladesh's GDP in 1989/90, calculated at 638billion taka (US\$ 17.83 billion) would increase by $29 \%$ to 825 billion taka (US\$ 23.05 billion) if unpaid work were included. Similarly Hamid calculated that the percentage of national production attributed to women would increase significantly from $25 \%$ to $41 \%$ if unpaid work were included in the national economy. The amount contributed by men automatically would fall $75 \%$ to $59 \%$.

2 Hamid, S. (1994) "Non-Market Work and National Income: The case of Bangladesh "The Bangladesh Development Studies; Vol.XXII. June- Sept. nos. 2\&3. Bangladesh

Full

http://www.jstor.org/discover/10.2307/40795507?uid $=3737584 \&$ uid $=2129$ \&uid=2\&uid=70\&uid=4\&sid=56204255923 (Accessed date 25/5/2012)

\begin{tabular}{|c|c|c|c|}
\hline \multirow{2}{*}{ Production } & \multicolumn{3}{|c|}{ Percentage Distribution } \\
\cline { 2 - 4 } & Total & Male & Female \\
\hline $\begin{array}{c}\text { Accounted under } \\
\text { conventional GDP }\end{array}$ & 77 & 98 & 47 \\
\hline $\begin{array}{c}\text { Additionally accounted for } \\
\text { in 1990 Revised SNA } \\
\text { (Subsistence) }\end{array}$ & 1 & $*$ & 2 \\
\hline $\begin{array}{c}\text { 65+Unaccounted } \\
\text { (Housework) }\end{array}$ & 22 & 2 & 51 \\
\hline Revised GDP & 100 & 100 & 100 \\
\hline
\end{tabular}

* Less than $1 \%$

Women entrepreneurs constitute less than $10 \%$ of the total business entrepreneurs in Bangladesh whereas women in advanced market economies own more than $25 \%$ of all businesses. Moreover the constitution of Bangladesh has failed to guarantee women's equal opportunity as well as safety in every formal and informal sector irrespective of sex, race, caste or ethnic group. In addition tasks performed simultaneously are often under reported and the intensity of effort is not counted: -the burden of unpaid and paid work respectively is distributed unequally between men and women. As a result men receive the lion's share of income and recognition for their economic contribution -while most of the women's work remains unpaid, unrecognized and undervalued (UNDP, 1995). Why workers particularly women workers are under counted and why women's work invisible? Why women's work is predominantly seasonal, intermittent and uncertain as they work frequently work as unpaid workers on family farms or in informal sectors, which are not properly recorded. Considering these questions this paper seeks to address the policy response to the empowerment of women in the informal economy through the national gender policy. It would help to ensure more equitable linkages between the formal and informal 
economies and would likely lead to mutual benefits of operating formally or informally (Cain, 2004). These are wider structural factors that need to be taken into account as they determine whom accesses resources and the markets, who benefits and who does not.

\section{Section Three}

The following section questions the dichotomy between work and non- work. The analysis clearly stated that the dilemma between paid and unpaid work started from the way in which work is generally defined.

\subsection{What Is Work; Unanswered Questions}

What constitutes work as an activity? Work is a source of personal identity. Consequently work and occupation are important bases of social evaluation. Therefore, work and occupation are solid social facts that condition life chances (Coleman, 1978:47). Particular values and functions of work are specific to time and place and the meaning of work responds to variations in social structure. In the case of Census of Population the term work has been defined as any productive work for which remuneration is paid and is market related and "worker" is a person employed in "work". Thus Mills defined

Work is a source of income; the amount level and security of pay and what one's income history has been are part of work and in the general community... work also carries various assorts of power, over materials and tools and machines but more crucially now over other people $(1953 ; 230)$.

There have four crucial features for defining the definition of work such as:

Firstly, formal work endorses the wider social participation or citizenship of the individual. Formal employment means 'the right to accede to the public, economic sphere through one's work is a necessary part of the right citizenship. Work gives the individual access to an important source of public legitimating and status (Shelton, 1996). Secondly, work is that which is within the public sphere. Activities carried out under an agreed contractual agreement, in a particular time and place, which are declared for the purpose of taxation. Thirdly, work involves some form of exertion or effort is relatively self-explanatory. Fourth, work is only productive activity. The official definition of work in Bangladesh is based on ILO definition:

A person aged 15 years or above who was either working one or more hours for pay and for profit or working without pay in a family, farm or enterprise or organization during the reference period or found not working but had a job or business from which he/she temporarily absent during the reference period

\subsection{Unpaid Work/Non Work; As an Analytical Tool}

Unpaid work can be understood to comprise all productive activities outside the official labor market done by individuals for their own households or for others. Unpaid work includes all non-remunerated work activities, which lack social recognition. Unpaid work is 'non-market' work and includes activities such as housework, care for children, the sick, and the elderly voluntary community work, work in political or community organizations; subsistence, agriculture, fuel and water collection. Reproductive labor is defined as unpaid work that is necessary to ensure the daily maintenance and ongoing reproduction of the labor force. Reproduction is of two types: one is biological and another one is social. (Beneria,1982).

a Biological reproduction refers to giving birth to new human beings, an activity which only women can perform.

b Social reproduction refers to all caring and nurturing activities necessary to ensure human survival and maintenance.

Folbre ( 2000) defined that housework which services other members of a household and family. These definitions may not always enable differentiation between work, non -work and leisure. Caring is predominantly female activity and its study appears both to demand an analysis rooted in the gender order and facilitate the development of knowledge on the oppression of women. Definitions of care are complex because it is multifaceted. The concept of care is based on seven distinct interlocking variables.

a The social identity of carer: gender is the social identifier for this dimension of care. Such as wives, mothers

b The social identity of the care recipient; care recipients in terms of dependency group such as children, older people, disabled, social group such as family.

c The interpersonal relation between carer and carer recipient: friendship, neighbors

d The nature of care: an activity and feeling state.

e Social domain within which caring relationship is located; social division of labor in capitalist society

f Economic character of cares relationship; waged and unwaged status of caring work.

g Institutional setting in which caring is delivered; home as the main institutional setting. 
Table 1. A number of concepts can be developed by using different variables:

\begin{tabular}{|c|c|c|}
\hline $\begin{array}{c}\text { Different variables of } \\
\text { Care }\end{array}$ & $\begin{array}{c}\text { Accepted } \\
\text { phenomenon }\end{array}$ & Expected phenomenon \\
\hline Social identity of care & Women & Men and women \\
\hline $\begin{array}{c}\text { Social identity of } \\
\text { recipient }\end{array}$ & Dependents & Dependents \\
\hline $\begin{array}{c}\text { Interpersonal } \\
\text { relationship }\end{array}$ & Familial & Familial \\
\hline Nature of the care & Work activities & Work activities \\
\hline Social domain & $\begin{array}{c}\text { Domestic and } \\
\text { Private }\end{array}$ & Domestic and private \\
\hline Economic relationship & Unwaged & Recognition or waged \\
\hline Institutional setting & Home & Home residential institution, long stay hospital, community social service unit like day care \\
centre, old home etc.
\end{tabular}

The feminist movement of the late 1960's and 1970's had major impact on popular and social science definitions of work and created a new language to describe unpaid work and domestic work. Sociologists were more receptive than economists to seeing work as socially constructed category (Hartman, 1976). In the process, meaning of work is embedded in society. This new focus extended the concept of work to include labor that was not directly economic (Glucksmann, 1995) and also Marxist feminist (Hartman, 1976) and labor economists (Becker, 1991) to explore the hidden economic value of these bundle of works. The increasing lack of formal employment opportunities forces many workers to take up self employed work, often at or from the home. On the other hand, global contracts is forcing many to cut costs through more flexible work contracts or subcontracting thus leading to the increase in the number of women employed as piece rate workers. To capture the variation in available work opportunities and available opportunities in the context of Bangladesh we organized four categories of work: a) paid work and b) unpaid work c) subsistence work d) economy inactivity or voluntary work. Women remain concentrated in invisible areas of informal work, which offer precarious employment status, low, irregular or no remuneration, no access to social security and human rights (Heintz, 2006). Economic analysis will not tell us how much a woman investing her time on cooking, cleaning or childcare or how much time they are using for informal work and what kind of life they are continuing. Women's contribution is not counted as formal work in such sector even though they are responsible for the majority of the work done is these sectors and often these works are associated with subsistence economy, which is not counted in the GDP. The following explanation will clearly state that unpaid works are situating women's vulnerable condition where women are working as an active agent but perceived as passive dependents. The study shows that abstracting women from their social realities eclipses the relational nature of gendered power and inter dependency of women and men and paints distorted picture of women's choices and possibilities. The double burden of paid and unpaid work undermines women's quality of life and is profoundly disempowering. These obligations pose a serious obstacle to women's labor force participation and have major impact on their lives and well being more broadly. As we have discussed above that unpaid work underpins much of this being both a major 'barrier to women' economic empowerment". In many ways it is the social issue; the missing part of empowerment equation. Recognizing and addressing the enormous time and effort consumed by unpaid work must be a priority if we are really serious about empowering women. It also manipulates their relative standard of living, as measured by national income statistics. Reliance on estimates of the total value of marketed output fail to capture important dimensions of women's lived experience. Although women are contributing there time and labor but "no wage" and "no recognition" is placing them as dependent and inactive agent in our society. Unpaid workers do not get equal position like the paid workers in any society. Hierarchically paid workers have some social status and society can easily address them but unpaid workers situation is, "they are no-where".

\section{Section Four}

\subsection{Revisiting Unpaid Work through Feminists Lens; Costs of Unpaid Work}

The conventional view of the household as a simple corporate unit (Becker, 1976) does not encourage investigating the internal diplomacy of the household. But it has been argued by Folbre that there are considerable and persistent gender based inequalities in allocation of productive resources and distribution of benefits (2000). Sharma stated that in 'the feminist discourse the household is no longer an irreducible unit, it has an inner politics of its own which is not divorced from the politics of the society in which it is embedded" (1986:3). Opening the black box thus can prove to be the starting point for research which takes a close look at the way power structures within the family are not only generated, reproduced and legitimized and so on. Agarwal (1997) describes household have multidimensional actors with varying preferences and interests and differential abilities to pursues and realize those interest. Housework 
inequality is a form of exploitation, which is experienced by women in relationship with men. Although Bangladesh is patriarchal, there is a common perception about women staying at home to do particularly home based work and care for the children (Mahmud, 2002).

We can say that economic independence does not bring social independence. The male identity is still entangled with being the "breadwinner", while the female identity is still enmeshed with being the "'caregiver". Women's work and role have shifted by participating in labor force participation, though there is a new crisis for women to bear the "double burden". Consequently women should continue to perform acceptable amounts of domestic labor and at the same time men should not have increased unpaid work time at any substantial degree. When financial pressure challenges men's adequate economic capacity, women get the entry point to tackle men's position in challenging financial gap but not men's capacity. It has been revealed, that women's income is a supplement rather than a replacement for male's wage. The shifts in women's labor force participation have not altered the household division of labor, so there is a weak link between labor market and household for women only. The gender perspective implies that women should have less free time than men because women are responsible for ensuring that all housework work gets done regardless of how much time they spend in paid work. Findings from cross sectional document that women do more housework and child care than men and marriage, children and employment increase women's household labor but has little effect on men's unpaid work ( Blau and Ferber ,1986). Parents' couples spend considerably more time in paid and unpaid work and have less free time compared with non parent's couple and the difference has increased from 1965 to 1998. Studies of dual career families (Shahra,2009) have found that even when wives are employed in high-level professional positions they still have to bear major responsibility for domestic chores. Married employed women may show a "toleration of domestication," changing their family life styles a very little despite the addition of professional roles, because of early socialization patterns for women and supports by the existing social structures (Kandiyoti,1988). Safa's (1995) study has shown that volume of unpaid work changes and determined by class variables. Upper and middle class have alternative options for replacing their work volume. Gender as an analytical concept focuses on women's roles and responsibilities in relation to those of men. Okin (2008) points out that 'gender is the deeply embedded institutionalization of sexual difference'. In this context, it is not surprising that women world over are disadvantaged in terms of access to resources and power in relation to men. Hirway (1999) argued that this ideal model of household ignores the structural differences that operate as more interpersonal issues. Women's continued acceptance of responsibility for these chores can be seen as the other side of the coin to surrendering their capacity to work outside. Overall, women's share of paid work hours has been increasing at a very high rate. The unequal division of time spent on unpaid work acts as a part of a vicious circle that leaves women economically and politically disadvantaged; thus resulting economic dependency which reduces their ability to assert their own time needs in the home and makes them more vulnerable to exploitation and abuse. Housework inequality is a form of exploitation, which is experienced by women in relationship with men. Women as well as men legitimize male control over women's time and work participation. Revealing the hidden cost associated with unpaid care work is merely the first step in understanding the complex relationship between the distribution of responsibilities for meeting needs as influenced by public policy and the distribution of costs.

In the context of Bangladesh women are accepted primarily as homemakers, women's rightful position in the society is housewives that are their first identity. Most of the women are negotiating with outside job but they have no options of negotiation with unpaid care work. Women's double- day- work is one of the most non -controversial issues in this society. As we have demonstrated from a variety of geographical locations, where most of the women seek to redistribute household tasks generally to other women like from mothers to daughters or other female relatives or female maidservants. So housework is women's work. Women are still regarded as inferior to men within the household, the society and under the law. Thus if policy initiatives that will improve the material and social condition of women and promote social changes are to be devised there is a need to understand how profound and pervasive the structure of women's subordination really is. Subordination of women is used to describe the generalized situation where men as group have more social and economic power than women. Policies and intervention programs failed to improve women's situation because their dependence on conventional theories that treat the household as a unit without paying attention of intra- household relations and power differentials which bring negative impact towards women. The need for a gender analysis of paid and unpaid work, which is based on the premise that men and women experience and respond it differently; cause and consequences are gendered. Inclusive growth cannot be achieved with gender blind policies. This paper has highlighted the structural disrespect of uncommodified unpaid care work in the private sphere in contrast to the structural recognition of paid work in the public sphere.

\section{Section}

\subsection{Housework in Bangladesh; Inequality between Men and Women}

Although large numbers of women in one part are doing outside activities, women in most other parts of the country are fully involved in household activities that mean they are housewives. Thus, the female labor participation rate in table is low as it covers women in a country as a whole. The 
distribution of time allocated to unpaid work across non-poor and poor households shows a lot of variation (Hochschid, 1989). Women's contribution is underrepresented in Bangladesh since labor force surveys have been unable to capture their multiple activities adequately.

Table 1. Population engaged in full time Housework or paid employment:

\begin{tabular}{|c|c|c|}
\hline Employment Category & Women & Men \\
\hline Urban housewives/household work & 24.5 & 0.5 \\
\hline Rural housewives/ household work & 18.8 & 0.4 \\
\hline Total housewives/ Household work & 43.3 & 0.9 \\
\hline Urban Employed & 2.5 & 8.2 \\
\hline Rural Employed & 7.3 & 26.3 \\
\hline Total Employed & 9.8 & 34.3 \\
\hline
\end{tabular}

Source: BBS 2005; Numbers in million

Women living in rural areas perform a wide range of activities related with the household than women in urban settings. It is important to note that there is a difference in time spent on housework between rural and urban areas:

I. Urban sector: Bangladesh Bureau of Statistics report wise 53.2 million people are engaged in housework full time where 43.3 million are women and 0.9 million are men (BBS, 2012), working about 16 hours day on an average. In Bangladesh time allocation studies estimated that women's contribution to total work load ranged from $50 \%$ to $58 \%$ and that for women hours of total work remained more or less constant for all socio economic classes (Khuda, 2008).

II. Rural Sector: To understand the extent of sex-based activity in rural Bangladesh it is important to have knowledge of rural settlements. Their primary unit is a Bari, which consists of two or six houses around a square or rectangular courtyard. The existent social system dictates that women specialize in the task that can manage the Bari. They fetch water, clean house, and cook, serve meals, wash dishes, and care children raising poultry, tending of livestock, and growing vegetables. Rural people in Bangladesh are dependent on traditional technology for household management. So water collection is almost a female activity. Women in rural Bangladesh spend nearly five hours daily on housework and about an hour on subsistence production (Mahmud, 2002). In addition men spend a negligible amount of time on housework and devote less than half an hour daily subsistence work. In case of women aged group 10 to 64 shares the burden of work almost equally. Mobility and employment opportunities of women have traditionally been restricted in rural Bangladesh. Barkat $\mathrm{E}$ Khuda focus that work is seasonal fluctuations in the employment structure in rural areas. Moreover Men and women from nuclear households enjoy the highest leisure compared to extended family. Women sometimes work with husbands in nearby fields to harvest pulses, mustard or at ponds to clean jute. So the activity pattern of rural women in Bangladesh is dependent on gender, class and age and religion, traditional technology and season. Linked to the issue of substantive equality must be the recognition that women are not a homogenous group. If we apply the intersectionality lens, we will get the clear picture that the situation and needs are not same for all women in our society. Therefore, their heterogeneity requires us to take into account the fact that women do not experience discrimination and favoritism in the same way. Consequently, the sameness approach cannot protect and promote women's rights as women have been in disadvantaged position by different reasons.

Housework increases with the size of the household but appears to be different on the ratio between men and women. In addition the size of female space for paid and unpaid varies regionally in Bangladesh as the district of the country differs from each other in economic condition and in practice of purdah (Kanti Paul, 1992). The proportion of time spent on unpaid or domestic activities confirms to that abstract notion of 'work' and work is becoming more and more concentrating in the 'paid economy'. The activities remaining in the home are more personal aspects of domestic life, which are least easily assumed under the dominant notion of "work" and retain the characteristics of invisibility that used to characterize unpaid work. Systematic underreporting and misrepresentation of women's contribution in the economy ...perpetuate a vicious circle of inequality between women and men. These inequalities are based on and linked to gender lines as well as class (poverty, education), rural/urban distinctions, ethnicity, religion, age, etc. In the context of Bangladesh the informal economy is largely unregulated, unrecognized and the informal workers operate as a heterogeneous lot with no fixed station. Organization and representation of the informal economy has thus been a great challenge. However, there is generally lack of pension for these workers and this makes them more vulnerable during old age. The existing legal framework and infrastructure makes it difficult for unions to organize informal workers. This is not only due to insufficient resources but also due to lack of political will.

\section{Section Six}

Failure to recognize the economic value and extra ordinary extent of unpaid domestic and community services have thus led to insensitive and ineffective policies which have also reinforced and undermined women's lower status in the society. This study will push the boundaries of much current Marxists thought and will seek to expand a materialist framework to account forms of labor that lie 'outside value". Politically and in terms of women's representation, policy approach towards the empowerment of women is silent on shifting opportunities towards equality for women on the supply side. In addition, the dual legal 
system has been an impediment in terms of the rights for women, which in turn lower their level of economic activity. On the demand side the women's agency has not been strengthened as there is inadequate representation in policy dialogue and hence women cannot hold policy makers to account on matters affecting them. Sen (1990) has observed that there is frequently reluctance in the development literature to consider the position of women as a separate problem that is important on its own.

\subsection{Counting Unpaid Work is the Basic Path of Gender Equality between Men and Women}

Providing paid work for women is one way to become productive labor force but socially prescribed roles lave limited access to economic resources. If we unpack the household no doubt people will get the smell of patriarchy their gendered ideological construction emphasized several separate prescriptions for women. Empowerment is the only solution for giving equal status to women in any society. There is a need for more sustainable and transformative strategies that address the social issue more comprehensively.

Most of the women's work fall in the domain of non monetized segment of the economy which has not been counted in national accounts, perpetuating the myth the that women have not been contributing as much as men in the economy (ESCAP, 2003). The artificial macro and micro economy perpetuated the belief that women's unpaid work and reproductive activities were not of any real significance (Hirway, 1999). The care economy of unpaid work that sustains the current labor force raises the future workforce. The underestimation of unpaid work in economic terms is partly due to limited definition of economic activity, which considers economic value synonyms with market value (Hirway, 1999). The failure to recognize the economic value of unpaid work leads to the beliefs that people who spend their time on caring for others without compensation are unproductive, inactive unemployed and outside the business cycle. The importance of recognizing the economic contributions of all forms of work -paid and unpaid- as a precondition for achieving- gender equality. The gender division of labor between paid and unpaid work has resulted in women being concentrated in economic activities with low earnings, irregular jobs where there is little protection of labor laws. Interventions are needed to promote gender equality by allowing women to devote more time to higher productivity and reducing the time spent on unpaid work in rural and urban areas (Hirway, 1999). Through the years, the economic value of unpaid work was ignored and economic theory has supported this implicit gender bias. Analysts have noted that there is no inherent reason why some activities are remunerated and some are not; the same activity may be paid or unpaid depending on the social and economic context.

Measuring unpaid work was one of the major challenges of governments that emerged UN third world conference on women in Nairobi in 1985 and the UN fourth world conference on women in Beijing in 1995. The process of imputation only can make women's work visible, influencing concepts and policies and questioning values. Demands for the full recognition of women's economic production culminated in the platform for action adopted in September 1995 at the Fourth World Conference on Women in Beijing. Becker (1976) conceptualized households as not only main driving economic force for the market economy but also as the most important agent in the grants economy. We note that there has been significant rhetorical recognition of the importance of gender in political economy at the level of policy making. But the shift to counting unpaid work and household work as part of the economy has not been fully implemented. The concept of economic citizenship is used to emphasize the rights of citizens as workers and as economic contributors. Scholars argued that the work of reproductive labor was indispensible to the ongoing reproduction and maintenance of the productive labor force (Hartman, 1976). The fallacy of ignoring these features of economy first pointed out by Hart (1997) and generated a wealth of literature and debates between those who viewed that unpaid work is marginal and peripheral to economic development and others who considered unpaid work is the dynamic form of development. The time women spend in unpaid work is time women can devote to paid work. Conventional data on GDP do not generally include the goods and services produced for self-consumption within the household. It could raise 50 to 60 percent of National Economy (Peterson, 2005)

It was found that nonmarket work about 190 billion annually, women contribute $95 \%$ of which. Own account production answers for only 5 percent of this amount and rest of the amount $95 \%$ being created through housework (Hamid, 1996; 35). It was observed that the opportunity cost on average was about $81 \%$ of informal wages although the patterns of the two wages are almost equal. The formal, informal and opportunity cost indicated a tendency of self-exploitation and undervaluation of time spent in subsistence and housework production in rural Bangladesh. In this case, the national policies should be reviewed and revised in order to incorporate and include women's participation in the subsistence economy in the national economy. The perception of the mass people regarding workingwomen and their work should be taken into consideration. Feminist economists are giving thoughtful attention to the implications of paying for unpaid care work. Most of the feminists are calling for a high degree of co modification of unpaid work that the present gender system assigns as duties to the female caste as a means to gender equity (Becker,1991). We need to measure and value unpaid work; that much is agreed. So we will have to identify the most efficient system, which can open up the other eye of statistical binoculars, with which we view the economy. The importance of policies to address and improve the situation of women cannot be overstressed. The reality is positive changes by which women's situation not only benefits them but also benefits from other members of their household and 
society as a whole. Further it is necessary to bring these policies together in more a holistic perspective that encompasses productive and reproductive work.

Policy is usually constructed within a certain ideology that frames the interpretation serving particular interest groups that may be at the exclusion of others. Ideology in this context is a coherent and relatively stables set of beliefs or values. Dominant ideologies appear as neutral holding on to assumptions that stay largely unchallenged. For instance the outlined objectives as stated in the policy assume women entrepreneurs are homogeneous. The policy discourse analysis must examine the framing of the problem in relation to the generation of answers offered. Only then can we see what is implied, suppressed or forgotten. In this sense the policy is not so much in touch with the reality of women entrepreneurs. For instance, the policy is silent on addressing the cultural inequalities that constrains the mobility and ability of women to engage in productive work (Pearson, 1992). The policy has a good ideology of removing barriers that constrain women's participation in trade but yet it is not addressing a crucial element of their inability to do so, which in this case is their dual roles. The gender division of labor at household level is embedded in cultural norms and ideologies and for some of these ideologies to change; gender sensitive values must be promoted at the policy level. Therefore, the silence of the policy in addressing cultural constraints amounts to perpetuating the status quo of women because it does not address the stereotypes of women associated with infringement of their freedom and choices. The policy is equally silent on addressing gender sensitive language in communication. The policy is also silent on addressing the contradictions in the legal framework. The dual legal system has been an infringement on the rights of women's economic empowerment. It has meant women having less access to factors of production. The vision of the government to empower women by removing barriers in trade is not linked to this reality. The policy says one thing and the legal framework says another.

This paper argues that women's contribution has largely been unacknowledged in policymaking process. The present review shows that there is an explicit gender division of labor within the household sector, informal sector and subsistence sector. Men predominantly do market works and women predominantly perform income conserving work including post-harvest activities and domestic work. We turn now to consider different aspects of this changing context, which cumulatively are rising new questions about unpaid work and its future such as- who will do this work? Who will pay for it? How will it be structured and understood? Should unpaid work be given a separate field of policy, provision and practice? In this way the wider contribution of caring might be recognized as a productive contributions rather than social costs.

\subsection{Global Study vs. Global Lens to Measure Unpaid Work}

If the unpaid work is given recognition in economic terms we can outline two alternative ways -separate but equal or integrated -in which unpaid work could be counted. Duncun Ironmonger claimed that "we need a major change in view of our reality (...)"'. The reality of huge unpaid households to economic value needs to be accepted; adopted as a benchmark fact; it would change our social and economic policy (Fraser, 2003). Folbre (2000) argues that public investments should be made in formal care supports to relieve overburdened family caretakers. Loss of family wage, greater work load and rising women's labor force participation have intensified stress on parents especially mothers. Across the US employers are voluntarily instituting work/life policies to reduce worker stress. Economists will face critical challenges in integrating unpaid work in their scientific endeavors. Therefore four elements of modern gender equality policy are discussed:

I. Promoting a more equal sharing of unpaid work between men and women: Direct state intervention to persuade men to accept equal sharing of unpaid work. In case of lone mothers, singles of all ages lacks sharing partner.

II. Rearranging of work: Introducing changes in the organization of paid employment in order to facilitate the individual combination of paid and unpaid work. To bring change in formal organizations through adopting family friendly policy such as maternity leave, paternity leave, leave to care for sick dependents are less controversial than the issue of working time.

III. The provision of public services: Palmer, Elson and other scholars argue that publicly financed infrastructure (road, transport, water, market ) facilities and other social services can demolish the burden of unpaid work

IV. Commercialization of domestic labor: Policy approach would have to compromise tax deduction

In recent year time use data has facilitated the construction of satellite accounts capturing production outside of the SNA production boundaries. Social accounting matrix (SAM) analysis is an effective way for examining the interconnection between paid and unpaid work (Beneria,1982). Three different approaches were used for valuation namely the opportunity cost approach, the replacement cost approach and which is also subdivided into specialist coast approach and generalist cost approach. In other words while being aware of the right to be paid for care work they also felt deeply for notions of love, marriage, home which was unfortunately beyond the nexus of cash transactions. Effective and relevant actions are required to improve the disadvantaged position of women, which can be achieved by harmonization of research, policy and action. Beneria $(1982 ; 31)$ has shown few significant policy options in her study, such as:

a Universal provisioning: Under the Nordic Model, state becoming a direct provider of childcare, after school 
programs, eldercare and health care education services. This model stands in direct opposition to the US tax credit programs and that provide an allowance to families allowing them market choice in which market system remains the main provider. This system mainly combined generous parental paid leave and other tax incentive that have indeed resulted higher market participation of women. In addition the majority state employed workers who provide the caring of women and that has raised concerns for few researchers (Ironmonger,1996))

b Employment Guarantee based: Unpaid work hours coexist with deficits in employment especially for unskilled workers. Structural constraints and insufficient demand for labor market disproportionately excluded women workers. Thus public employment guarantee programs invested much more infrastructure projects such as construction and maintenance of social services. These programs are gender informed in design and implementation and context specific. In can translate the public investment infrastructure that reduces unpaid work such as rural water projects, feeder roads, which will decrease the time allocation to fetching water. The unpaid work can be truly reduced only when redistributing the cost of reproduction by creating jobs both for women and men instead of reinforcing the existing gender based division of unpaid work. If the projects are not gender neutral there is a possible chance to create a typical double burden for women.

c Family based cash transfers: This intervention provides a grant of targeted poor households with children on the condition that in exchange for a monthly cash payment the mother of the child will ensure the child's welfare in short run and employability of long run. Participating in cash transfer programs will be still in need of fetching water, taking care of infants. Women may be happy to contribute their time to their children's future but they need separate programs that can ensure their own economic security through training and links to employment (Ironmonger, 1996).

d Family work reconciliation policies: The main objective of this policy is to create effective equality opportunity and treatment both for women and men in the labor market. Reducing work -family conflict is in the interest of higher productivity, lower turnover rates and costs and reducing absenteeism (Ironmonger, 1996). Furthermore employment diversity is an important issue where employers can form a way of creating and maintaining competitiveness. Wages for housework is a temporary solution because it may decrease as soon as the children are grown up. Therefore this idea would not enhance women's economic independence in the long run because it could formally discourage women's labor market participation. It may contribute of marinating the traditional division of labor between man and women instead unfreezing it.

\subsection{Local Study vs. Local Lens to Measure Unpaid Work}

The above literature review on unpaid work carried out an important issue for changing the unequal situation between men and women. As a developing country we need to consider this issue separately in development process. Government of Bangladesh has acknowledged in its Poverty Reduction Strategy Paper (PRSP) that the contribution of women through their unpaid work must be calculated and properly credited. In this case, the national policies should be reviewed and revised in order to incorporate and include women's participation in the subsistence economy in the national economy. For instance Bangladesh Bureau of Statistics could elaborate a list of different tasks like location, age, class, ethnicity which list could be used to calculate the economic value of unpaid work. In Bangladesh the objective of women's action is still around Bengali women's issues. The mainstream women's movement and women's organizations have not yet touched indigenous women. Khuda (2008) has pointed out that women's contributions in the national economy are only $20 \%$, which is neither sufficient nor appropriate. The study has shown that most of the women are preoccupied of doing unpaid work because most of the women love to do this care works and should not have any monetary value attached to it. The study presented a calculation according to which if women's care works are counted in the GDP then it would constitute $53.4 \%$ of the GDP. This contribution is not counted, not recognized and mostly ignored owing to a patriarchal mindset. The study recommended opportunity cost for women's contributions in Bangladesh. This study only elaborates the interpretations of some quantitative information, where the in-depth analytical vision is missing. It seems that the author has used the time use survey and then tried to incorporate a minimum wage for the hours spent in the household works. This approach seems somewhat relevant with opportunity cost. In addition Hamid (1996) intends to develop a new system of national income accounting, which can better reflect women's contribution to the national income in Bangladesh. Hamid hound that the most relevant methodology for evaluating time spent in subsistence work and housework and create value through market replacement costs.

The study spells out that patriarchal structures create gender asymmetries endowments, risks and constraints which penalize autonomous behavior for women but also offer them provision to remain within it parameters. It is very important to shift the focus from approaches that treat women as victims of development who are waiting to be rescued. The planners should consider that woman as a social agent and that is a necessary to take an agent oriented approach on women's agenda (Sen, 1990). Therefore women need to be assisted through holistic approach and comprehensive programmes that not only address their lack of productive resources but also their subordinate situation within households and society at large. In sum, there is a need for multipronged policies to address the needs of different categories of women in Bangladesh. Thus social 
dialogue and public debate is more powerful for transforming traditional mentalities or cultural norms. There is no doubt that social dialogue takes different roots, new ideas and brings diversity. Women should engage themselves more actively in a constructive debate with policy makers and negotiate the conceptual and policy issues that affect them directly. Wieringa claimed that on question of transformation "women should learn to define their own problem $(1994 ; 844)$. Gender equality cannot be attained in the absence of equal rights and women themselves have to be the active agents for this change. Therefore, a more critical understanding and analysis of political, economic and social realities being faced men and women in developing countries is needed, otherwise gender equality interventions designed towards that end will always be a fallacy.

\section{Conclusions}

This is the biggest challenge of the policies designed to lift the position of women, the intent is good but when it comes to implementation there are neither clear channels of execution or monitoring. This in turn has had a ripple effect in producing inequalities in terms of ability to enhance market-relevant skills. Improvement of women's situation cannot be achieved without an understanding of the difficulties they face and the needs they have. This is what this study has attempted to unearth. Effective relevant action to improve the disadvantaged position of women requires harmonization of research, policy and action.

\section{REFERENCES}

[1] B. Agarwal. Bargaining and Gender Relations: Within and Beyond the Household, Feminist Economics,Vol.3, No.1, $1-51,1997$

[2] Bangladesh Bureau of Statistics (BBS) Statistical Yearbook of Bangladesh, 2012

[3] B. A. Khuda. Narir Khomotayon O Valobasar Aurthonity. Bangladeshe Narir Aurthonoitik Khomotayon: Jatiyo Manob Unnoyon Porikolponaye Ja Vaabte Hobe. Dhaka, 2008

[4] G. Becker. A Treatise on the Family. Enlarged Edition, Cambridge: Harvard University Press, 1991

[5] G. Becker. The Economic Approach to Human Behavior, Chicago: University Chicago Press, 1976

[6] L. Beneria. Accounting for women's work in Lourdes Beneria' (ed) Women and Development; The Sexual Division of Labor in Rural societies. New York: Praeger, 119-147, 1982

[7] F. D. Blau and M. A. Ferber. The Economics of women ,Men and Work Englewood Cliffs, NJ : Prentice-Hall, 1986

[8] M. Cain, S. R. Khanam, S. Nahar. Class patriarchy and
Women's work in Bangladesh, Population and Development Review, Vol.5, No.3, 405-38, 2004

[9] R. P. Coleman, L. Rainwater. Social Standing in America. New York: Basic Books, 1978

[10] D. Efroymson, B.Biswas, S. Ruma. The Economic Contribution of Womenin Bangladesh Through their Unpaid Labor', WBB Trust- Health Bridge Dhaka, September 2007.

[11] ESCAP \& UNDP (United Nations Development Programme), Integrating unpaid work into national policies, New York: United Nations, 2003

[12] N. Folbre. Who pays for the kids? Gender and The structures of constraint, London and New York: Routledge, 2000

[13] N. Fraser. Redistribution or recognition?A political-philosophical exchange, London New York: Verso, 2003

[14] G. J. K. Gibson. Post capitalist politics Minneapolis, University of Mennesota Press, 2006

[15] M. Glucksmann. Why "Work"? Gender and the "total social organisation of labour, Gender, Work and Organisation, Vol. 2, No. 2, 63-75, 1995

[16] S. Hamid. Why Women Count, Essays on Women in development in Bangladesh, Dhaka: University Press Limited, 1996

[17] S. Harding. Subjectivity, Experience and Knowledge: An Epistemology from /for Rainbow Coalition Politics, Development and Change, Vol. 23, No. 3, 1992

[18] H. Hartmann. Capitalism, Patriarchy and Job Segregation by Sex. Signs I: 137-169, 1976

[19] G. Hart. From Rotten Wives to Good Mothers: Household Models and the Limit of Economism, IDS Bulletin 28(3):14-25, 1997

[20] J. Heintz. Globalization, economic policy and employment: Poverty and gender implications .ILO, 2006

[21] I. Hirway. Time use Studies: Conceptual and Methodological Issues with Reference to the Indian Time use survey paper presented' at the international seminar on Time Use Studies, Ahmedabad, India, 1999

[22] A. R. Hochschid, A. M. Hochschild. The Time binds when work becomes Home and Home Becomes Work, New York: Metropolitan/Holt, 1989

[23] M. N. Islam. Gender Analysis Migration from Bangladesh http://www.bmet.org.bd/BMET/resources/Static\%20PDF\%2 0and\%20DOC/publication/Gender\%20Analysis\%20of\%20 Migration.pdf, 2013

[24] H. Lopita. Unpaid care work in Bangladesh; Policies, practice and evidence, Institute of Development Studies, 2015

[25] D. Ironmonger. Counting outputs capital inputs and caring labor: Estimating gross house hold product, Feminist Economics, 1996

[26] ILO. Women and Men in the Informal Economy: A statistical Picture. Geneva: International Labor Office, 2007

[27] D. Kandiayoti. Bargaining with Patriarchy, Gender and Society Vol.2, No.3, 274-90, 1988 
[28] N. Kabeer. Reversed Realities; Gender Hierarchies in Development Thought, London: Verso,1995

[29] N. Kabeer. Paid work, Women's Empowerment and Gender Justice: Critical Pathways of Social Change, Pathways Working Paper, 3Brighton: IDS, 2008

[30] S. Mahmud. Informal women's groups in Rural Bangladesh: operation and Outcome in Judith Heyer et al Group Behavior and Development: Is the market destroying cooperation pp. 209-225, Oxford: Oxford University of Press,2002

[31] P. E. Mckenna. When Work Doesn't Work Anymore; Women, Work and Identity, Bantam Doubleday Dell Publishing Group, Inc, 2002

[32] W. C. Mills. White Collar Work :The American Middle classes, Oxford University Press, New

[33] S. M. Okin. Justice, Gender and Family, Family and Relationships, 464, 2008

[34] B. K. Paul. Female Activity Space in Rural Bangladesh; Geographical Review 82(1):1, 1992

[35] R. Pearson, Gender Matters in Development, in Tim Allen and Alan Thomas(eds) Poverty and Development in the 1990s Oxford University Press in association with the open University, 1992

[36] V. S. Peterson. How the Meaning of Gender Matters in Political Economy, NewPoliticalEconomy,Vol.10,No.4, 2005

[37] H. Safa. Myth of the male bread winner: women and industrialization in the Caribbean. Boulder, Co: Westview Press, 1995

[38] R. Shahra. From Global economic crisis to other economic crisis; Development 52 (3) 323-328, 2009

[39] A. Sen. Gender and Cooperative Conflicts, in I. Thinker(eds.) Persistent inequalities: Women and World Development, Oxford University Press, 123-145, 1990

[40] A. B. Shelton, J. Daphne. The division of House hold labor. Annual Review of Sociology Vol. 22, 299-322, 1996

[41] United Nations Human Development Report, New York: Oxford University Press, 1995

[42] S. Wieringa. Women's interests and empowerment: gender planning reconsidered, Development and Change,Vol.25, 829-848, 1994 